\title{
THE ECONOMICS OF LAND USE EXACTIONS: A PROPERTY RIGHTS ANALYSIS
}

\author{
William A. Fischel*
}

\section{INTRODUCTION}

A perennial story among undergraduates is about a philosophy course in which the final exam consisted of a single question: "Why?" Students who began their answers with "Because" failed. The only "A" went to the student with the wit and nerve to answer simply, "Why not?"

The law and economics school, which stems from Ronald Coase's The Problem of Social Cost, ${ }^{1}$ takes its cue from that brave but probably apocryphal answer: Why not? In the context of land use exactions, this approach asks how basic property rights should be allocated and legally protected. This society is accustomed to the idea that the right to develop rests with private owners of land. The rights of the community in which the land is located are traditionally thought to be limited to promulgating regulations that protect citizens from any adverse effects of the proposed development. Debate often centers on the proper scope of the community's regulations, but seldom focuses on the consequences of fundamental shifts in rights.

This article explores the implications of shifting basic property rights. Specifically, it examines the ramifications of declaring that the right to profit from development in any community belongs to the present, politically active residents of that community, and is freely alienable, saleable for cash to the highest bidder at an open sale, with proceeds going to reduce local taxes or to finance expenditures that benefit current residents.

II

\section{COMmunity BARgaining}

Suppose that a developer sought to buy four contiguous undeveloped acres in a privately governed community. ${ }^{2}$ He can subdivide the parcel into four one-acre lots as a matter of right, as stated in the deed, but he wants to double the density by building eight homes on half-acre lots. The

Copyright (C) 1987 by Law and Contemporary Problems

* Professor of Economics, Dartmouth College, Hanover, New Hampshire.

1. Coase, The Problem of Social Cost, 3 J. L. \& ECon. 1 (1960).

2. The type of community considered here is that written about in Reichman, Residential Private Governments: An Introductory Survey, 43 U. CHI. L. REv. 53 (1976). 
community's rules, to which all landowners agreed before purchasing their property, allow the homeowners' association to grant exceptions to lot size regulations if the existing property owners approve.

The developer enters into negotiations with the association. The following facts apply:

(1) The only spillover cost of the proposed higher density development is increased traffic congestion on community roads.

(2) This spillover effect could be entirely negated by road improvements that cost $\$ 150,000$. If these improvements were made, the development would cause no congestion.

(3) Current homeowners would accept the higher density development if the developer paid $\$ 60,000$ for road improvements and paid at least another $\$ 40,000$ to the association. The higher density would somewhat increase congestion on roads, but preexisting homeowners would accept the congestion in exchange for as little as $\$ 40,000$ to be divided among themselves. This payment of $\$ 100,000$ is assumed to be the least costly method of compensating the current residents.

(4) The value of the developer's property, once he obtains permission to develop on half-acre lots rather than one-acre lots, is increased by $\$ 175,000$. The same appreciation occurs regardless of whether the developer must build a $\$ 60,000$ road, as in (3) above, or a $\$ 150,000$ road, as in (2) above. ${ }^{3}$

Bargaining between the developer and the association will most likely result in the development being built at half-acre densities. Such a subdivision would yield the developer $\$ 175,000$ due to higher land values, while the community would be willing to accept as little as $\$ 100,000$ to tolerate the extra neighbors. If bargaining costs are not large, the parties will strike a mutually advantageous deal.

Building eight homes in the subdivision, each on half-acre lots, and requiring the developer to pay $\$ 60,000$ in road improvements and between $\$ 40,000$ and $\$ 115,000$ to existing residents constitutes a Pareto improvement in economic welfare. One party is better off and the other is either better off or no worse off than if the trade had not occurred. 4

The amount the developer must pay depends on the relative shrewdness of the two parties. The association will not accept less than $\$ 100,000$; anything less would leave its members worse off. The developer will not pay more than $\$ 175,000$ ( $\$ 60,000$ for roads plus $\$ 115,000$ in cash); otherwise he

3. A more realistic model allowing the developer's land to appreciate as a result of his additional road construction would yield the same qualitative result as this model reaches. For example, the developer's land might increase in value by $\$ 180,000$ if the $\$ 150,000$ road were built, but only by $\$ 170,000$ if the $\$ 60,000$ road were built. It is still more profitable for the developer to build only the $\$ 60,000$ road and compensate the homeowners' association $\$ 40,000$, since his residual rental will then be $\$ 70,000$ ( $\$ 170,000$ minus $\$ 100,000$ ), as opposed to a residual rental of $\$ 30,000$ $(\$ 180,000$ minus $\$ 150,000)$ if the larger road is built.

4. For a discussion of the Pareto criterion and its relation to property law, see Ackerman, Introduction: On the Role of Economic Analysis in Property Law, in Economic Foundations of ProperTy LAw at xi-xvi (1975). If the developer must pay $\$ 115,000$ to the community, he will be indifferent between building the more costly road and making the payment with the less costly road. 
would be better off building the four houses on one-acre lots, for which he need make no further compensation. The $\$ 75,000$ difference is up for grabs; it is the economic rent for the half-acre subdivision permission. Regardless of who receives the $\$ 75,000$ or any portion thereof, the outcome will remain the same: the eight houses will be built on half-acre lots.

One might object that who receives the $\$ 75,000$ affects the final result because if the developer is forced to pay, he may claim that he has to pass this cost on to the home buyers. This claim is not valid in this instance. Once the houses are built, their price in a free market depends solely on the demand for houses. The amount the developer paid for permission to build them does not matter, so long as the payment was unavoidable. It is unavoidable provided that the land cannot be used for a purpose other than that stated here.

To understand why who receives the $\$ 75,000$ is immaterial, suppose the developer had been given the land as a gift by his Uncle Sid. Would the developer lower the price of the projects built on that land? It is unlikely, unless Uncle Sid wanted to benefit home buyers instead of his nephew and specified that the houses built on the land were to sell for less than the developer would otherwise ask. If getting land free does not lower the price, having to pay more for land use entitlements should not raise their price, provided the extra payment is economic rent.

Suppose this problem involves a public municipality, in which the planning board and the local legislature, instead of the homeowners' association, negotiate with developers. Assume all other facts remain the same and homeowners are politically active residents to whom politicians pay close attention.

The developer will negotiate with community authorities in order to obtain permission to build. If a bargain is made, the developer will build a $\$ 60,000$ road and make compensatory payments to the rest of the community of between $\$ 40,000$ and $\$ 115,000$, depending on the shrewdness of his negotiator. The compensation to the community could take several forms. It could be a lump sum payment to the municipal treasury, which officials could then use to lower local taxes or to improve municipal services that benefit current residents. Alternatively, some of the compensation could be paid to neighbors who are more affected (or vociferous) than other members of the community. The developer could also make payments in kind: improvements in a local park, contributions to a housing fund, or construction of a museum. ${ }^{5}$ There is no reason to believe that the developer's plan created a need for any of these projects; rather, the projects are the developer's means of assuring the viability of his plans.

5. This article does not discuss the economic inefficiency of using barter rather than cash exchanges. On this topic, see W. Fischel, Economics of Zoning Laws 77 (1985). Examples of gifts in kind include a New York City ordinance that gave developers density bonuses if they made contributions to benefit Central Park, see N.Y. Times, Aug. 15, 1983, at B9, col. 4, and a Los Angeles developer who financed a new museum for the city in return for permission to develop a downtown commercial plaza, see Wall St. J., Apr. 18, 1984, at 22, col. 1. 
The analogy between private and public communities may seem strained because the public sector is seldom considered as possessing, let alone exchanging, land use entitlements. Land use controls are one of the community's police powers, and there is a strong aversion to the idea that police powers are community property that can be bought and sold. A number of traditional statutory and judge-made rules are designed to inhibit the exchange of police power regulations. As Part III will discuss, these restraints are inefficient in that they retard exchanges that would be mutually beneficial to the parties involved. ${ }^{6}$

\section{III}

\section{Restraints on Alienation of Land Use Entitlements}

Several legal doctrines discourage exchanges of land use controls. These include: (1) requirements that payments by developers be earmarked for specific expenditures related to the project itself rather than for contributions to the general municipal treasury, ${ }^{7}$ and (2) judicial barriers to contract zoning. ${ }^{8}$ Both of these doctrines will be examined.

In the example at hand, earmarking requires that the developer pay $\$ 150,000$ for road improvements that eliminate all the effects of congestion from the new development. Existing community residents are no better off than they would have been under a less extensive road improvement program costing the developer only $\$ 60,000$ and a cash payment of $\$ 40,000$. Since the earmarking requirement prevents the developer from making the cheaper cash payment, however, the municipal authorities naturally and rightfully will insist on the development option that produces zero congestion. Such an outcome is Pareto inferior to the cash payment outcome. The developer must spend an amount on roads exceeding the amount existing homeowners would have accepted as adequate compensation for the congestion spillovers.

It may seem odd that this outcome is deemed to be inefficient. It is often argued that government should internalize externalities. ${ }^{9}$ Some would argue that this statement implies that government should eliminate such spillover effects as pollution and congestion. Such an inference, however, is incorrect.

6. See infra text accompanying notes 7-11.

7. For a stringent example of earmarking, see Pioneer Trust \& Sav. Bank v. Village of Mount Prospect, 22 Ill. 2d 375, 176 N.E.2d 799 (1961) (exaction must be used solely for projects that are specifically and uniquely attributable to the development). Later decisions have allowed a greater latitude for payment of funds. See, e.g., Jordan v. Village of Menomonee Falls, 28 Wis. 2d 608, 137 N.W.2d 442 (1965) (requiring that there be a "reasonable connection" between the subdivision fees and the purposes to which they are put), appeal dismissed, 385 U.S. 4 (1966). Even the broader criteria suggested in Jordan still earmark the compensation for specific projects and thus could force greater expenditures by the developer than necessary to satisfy community authorities.

8. Judicial hostility to contract zoning is mixed. Some states permit it under certain conditions. See Lieberman, Contract and Conditional Rezoning: A Judicial and Legislative Review, URB. LAND, Nov. 1981, at 10,10-12. Some observers believe there is a trend toward accepting contract zoning. See Kmiec, Deregulating Land Use: An Alternative Free Enterprise Development System, 130 U. PA. L. REv. 28, 108-11 (1981).

9. See R. Musgrave \& P. Musgrave, Public Finance in Theory and Practice 77-87 (3d ed. 1980). 
The community internalizes externalities when it enters a contractual arrangement with the developer even if the contract does not require the elimination of such byproducts. The least costly outcome in this case is a partial reduction in congestion and compensation for the remaining spillover effects. Forcing a particular outcome, such as eliminating congestion, may expend too many resources on road construction, just as eliminating pollution would cause the expenditure of too many resources on pollution control. ${ }^{10}$

To illustrate the last point, suppose the cost of road construction to eliminate congestion were $\$ 200,000$, not $\$ 150,000$. Permission to subdivide would increase the value of the developer's property by $\$ 175,000$. If the developer must pay $\$ 200,000$ in road improvements to obtain approval from community authorities, he is better off not undertaking the project. Thus, four homes that could have been built under a more flexible system of cash compensation will not be built, or will be built on a more remote or less favorable site.

In addition to earmarking funds intended as compensation, prohibition of contract or conditional zoning imposes an additional cost on developers. In these cases, the developer has to make all road construction expenditures in advance without the benefit of an enforceable contract. Advance payment is required because the community would not want to grant the developer permission to subdivide and risk that he would not later perform the obligation. Making the advance expenditures, however, imposes greater risks on the developer. The community could take the donations and still forbid the subdivision. Even if the planning officials act in good faith, an intervening election could change the political authorities, and the newcomers may not feel bound by the understanding of their predecessors. This risk would prevent at least some developers from ever agreeing to this type of arrangment. ${ }^{11}$

From this analysis surfaces a curious implication: the dollar value of the exaction is not a measure of economic inefficiency. Critics regard exactions as exclusionary devices that restrict the supply of housing. ${ }^{12}$ But the dollar amount of the exactions themselves may be indicators of successful trades that increase the stock of housing. To illustrate this point, reconsider the example above. Suppose the developer agrees to build a $\$ 60,000$ road and pay $\$ 50,000$ to the municipal treasury. The community is satisfied with this amount and the developer builds the additional houses.

10. For a clear discussion of pollution and property rights, see P. HEYNE, The ECONOMIC WAY of Thinking 245-68 (1983).

11. An additional strategy the developer might undertake is to pay the exaction and then sue for a refund after the project was completed. See L. Geller, Strategy Zoning 117 (1983). If communities anticipate this strategy, they will be less willing to conduct any negotiations with developers.

12. See Bauman \& Ethier, Development Exactions and Impact Fees: A Survey of American Practices, Law \& Contemp. Probs., Winter 1987, at 51. 
As an alternative, suppose that exactions are forbidden by judicial rules, and the community therefore insists on a zero congestion standard, which the developer finds unprofitable to meet. No exaction is paid and no additional houses are built. The second scenario is inefficient. A housing development that could have compensated the community for its adverse spillovers is not built. Thus, the dollar value of exactions is zero. This example illustrates that the increasing popularity of land use exactions may be as good an indicator of efficiency as it is of inefficiency. The extensive imposition of exactions does not prove that exclusionary effects result from their use.

There are, of course, many exaction schemes that amount to inefficient taxes on capital rather than extractions of economic rent. For example, exactions imposing a uniform schedule of payments per square foot of office space are taxes on capital rather than on land rent. ${ }^{13}$ Owners of capital, unlike owners of land, have a choice of where and when to deploy their assets. As a result of exactions on capital, they may choose other locations or other types of investment in order to avoid such taxes.

\section{IV}

\section{Entitlements and their Protection}

Sections II and III of this article posit that a community ought to be able to sell the entitlements it possesses. This argument raises two questions: What should community entitlements be, and how should these entitlements be protected? The remainder of this article will address these questions. It will first posit that earmarking and similar restraints on alienation result from a desire to protect the developer's share of economic rents. It then advances an alternative approach to protecting landowner entitlements that yields less economic inefficiency than results from these arrangements.

The sale of development rights may be objectionable on the ground that it encourages the community to expand its regulations, thereby enlarging the scope of its entitlements for the sole purpose of raising revenue. Land use regulation thus becomes a form of taxation, with rules bearing only the skimpiest garb of protecting the "health, safety, and public welfare." This objection is implicit in the legal critique suggesting that impact exactions unrelated to costs arising from a particular development are taxes rather than regulations, and hence judicially unacceptable on either statutory or constitutional grounds. ${ }^{14}$

The distinction between the power to tax and the power to regulate, particularly in regard to contracts limiting those powers, has been criticized as a "formalism." 15 Since the collection of taxes and the enforcement of police

13. This practice is apparently in place in Boston, and is described in Connors \& High, The Expanding Circle of Exactions: From Dedication to Linkage, LAW \& ConTemp. Probs., Winter 1987, at 69.

14. See McNally v. Township of Teaneck, 75 N.J. 33, 379 A.2d 446 (1977); Connors \& High, supra note 13, at 106. See generally Juergensmeyer \& Blake, Impact Fees: An Answer to Local Governments' Capital Funding Dilemma, 9 Fla. St. U.L. Rev. 415 (1981).

15. See Kmiec, supra note 8, at 108. 
power regulations both ultimately rely on the community's monopoly on coercion, revenues obtained from taxes or regulations derive from the same source. Some influential economic models of local government treat the property tax in essentially the same way as the selling of regulatory powers. ${ }^{16}$

Formalism exists for reasons. The reasons are sometimes lost in the process of making the rules operational. The reasons for treating taxation by regulation differently from other kinds of taxes are outlined below.

The canons of taxation prohibit discriminatory taxes. Taxes are regularly applied to all members of a community in some measure or another. Because of this approximate uniformity of burden, the power to tax is self-limiting: if taxes become too onerous, voters can choose candidates who will reduce them. Land use regulations, on the other hand, are necessarily discriminatory. Zoning would make little sense if every parcel of land in the community had to have the same classification. As a result of such nonuniformity, however, such regulations often lack a political check. Existing residents can use regulations to provide for public goods such as open space without having to raise their own taxes. The owners of the undeveloped land bear the cost.

Fairness considerations may explain why selling regulation of a private community is less worrisome than selling the exactions of a publicly chartered community. In the private community, there is less opportunity to place special burdens on individual landowners because of the unanimous basis for the community's formation and the contractual basis for subsequent development. ${ }^{17}$ Publicly chartered communities are similar to private associations in that residents can choose in which community to live. However, majority, as opposed to unanimous, agreement governs collective choices in public governments. Furthermore, disgruntled owners of land and other nonportable resources cannot escape onerous regulation.

After an initial period of close judicial scrutiny of local regulations early in this century, federal and state courts have become increasingly reluctant to supervise them. ${ }^{18}$ This permissive attitude has not eliminated all judicial concern for the rights of landowners. Judges may limit the establishment of burdensome regulations by discouraging the sale of land use regulations as a revenue raising device. Without the potential to raise revenue from selling regulations, it is more likely that communities will establish only those regulations necessary for the public welfare. Speed traps provide a good example. Some towns used to set artificially low speed limits in order to collect speeding fines from unwary nonresidents. One means of discouraging this process is to require that traffic fines be earmarked for traffic control

16. See Fischel, Fiscal and Environmental Considerations in the Location of Firms in Suburban Communities, in Fiscal Zoning and Land Use Controls 119 (1975); Hamilton, Zoning and Property Taxation in a System of Local Governments, 12 URB. STUd. 205 (1975).

17. See Ellickson, Cities and Homeowners Associations, 130 U. PA. L. REv. 1519, $1521-26$ (1982).

18. See Williams, Planning Law in the 1980's: What Do We Know About It?, 7 VT. L. Rev. 205, 20811 (1982). 
rather than for general revenue purposes. Under this rule, towns lack any incentive to impose traffic rules beyond those necessary for general welfare.

The rationale underlying the formal distinction between taxation and regulation may be to protect those who are regulated from bearing disproportionate burdens. ${ }^{19}$ It should be apparent from the continuing controversy surrounding land use exactions that the formalism has not succeeded in accomplishing what is suggested here to be its underlying goal. Communities have adopted regulations that place special burdens on developers and prospective residents that were not borne by the current electorate. Neither the developer nor his clients benefit by making the regulation inalienable. Therefore, there is no reason to pretend that the problem is "selling regulation." The problem is that some citizens bear obligations from which others in similar economic circumstances benefit without sharing the burden.

How, then, can the legal system protect landowner entitlements while still permitting communities to exchange redundant regulations for more valuable assets? There are two approaches. The first considers how entitlements should be protected. The second considers what initial entitlements are appropriate.

\section{$\mathrm{V}$ \\ Property and Liability Rules}

If a community can normally refuse a developer's offers to change its regulations, the community's entitlement to control the subdivision is protected by a property rule. This rule contrasts with a liability rule, according to the distinction developed by Calabresi and Melamed. ${ }^{20}$

A liability rule protects the community's entitlement to control subdivisions only by imposing damage payments on the developer of the subdivision. The criterion for damages is that the community is not to be made any worse or better off as a result of the development. To see that this razor's edge is obtained, a third party, such as a judge, estimates the damages and monitors payment.

One approach to protecting landowners while maintaining the alienability of regulations is to protect the community only by a liability rule. The liability rule entitles the developer to subdivide if the compensation he offered left current residents no worse off than before.

The problem with this rule is that the least costly means of compensating residents requires obtaining subjective information that only the residents themselves can provide. The least costly means in the numerical example above combined $\$ 40,000$ in compensation with $\$ 60,000$ for road

19. This concern is related to the fairness considerations said to underly the fifth amendment's taking clause. See Michelman, Properly, Utility, and Fairness: Comments on the Ethical Foundations of "Just Compensation" Law, 80 HaRv. L. Rev. 1165, 1167-68 (1967).

20. Calabresi \& Melamed, Property Rules, Liability Rules, and Inalienability: One View of the Cathedral, 85 Harv. L. Rev. 1089, $1105-06$ (1972). 
improvements. ${ }^{21}$ (The road cost is subjective as well, since it implies a level of congestion that current residents are willing to tolerate.) Under a liability rule, however, community residents have no incentive to bear the costs of obtaining this information because they will be no better off if they disclose it. In fact, they have an incentive to exaggerate the cost of congestion. Such exaggeration will force the developer to spend more money on road improvements, which may make the whole project uneconomical. Residents would then be in a position to extract some of the economic rents from the development. The developer could then "volunteer" to pay more than $\$ 100,000$ in compensation.

The outcome of such a strategy is not necessarily inefficient. If the developer finally agrees to $\$ 60,000$ in road improvements and more than $\$ 40,000$ in compensation, the excess compensation is just an additional transfer of the economic rent. The process of discovering the damages that a community suffers from the impact of a development, however, may be costly. For instance, the cost of obtaining expert witnesses and court costs may be substantial.

As an alternative to the liability rule, I suggest a two-part solution: (1) limit the community's initial entitlements to the cost of eliminating nuisance spillovers; and (2) protect such entitlements by a property rule. In the example discussed above it cost the developer $\$ 150,000$ to eliminate the congestion. ${ }^{22}$ The community is entitled to elimination of congestion. ${ }^{23}$ This entitlement should be alienable and protected by a property rule. The community may be willing to accept a lesser standard and permit the developer to pay the community some amount less than $\$ 150,000$. It is uncertain that this alternative will result in the least cost outcome for the developer ( $\$ 60,000$ for roads, $\$ 40,000$ in compensation), but it will have two generally desirable effects.

First, the developer will not have to share any of the economic rent above the cost of road construction. Given that the total value of subdivision permission is $\$ 175,000$, the developer is guaranteed at least $\$ 25,000$. He may also be able to obtain even more by bargaining with the community. The developer is normally in a position to bargain effectively because of his greater experience and because he acts independently, whereas the community authorities must take into account the objectives of many different constituents. ${ }^{24}$

21. See supra text accompanying notes 2-6.

22. Id.

23. This analysis assumes that "zero congestion" is the normal state of affairs in communities of this type. One might argue, however, that initial residents of developing municipalities should normally expect that growth will bring some congestion and inconvenience to themselves. If this is a reasonable expectation, then the standard for which the developer should be liable is "normal congestion." This standard would prevent initial residents in such suburbs from using minor congestion of public facilities as an argument for halting growth.

24. The reasons for the developer's superior bargaining ability are developed at greater length in W. Fischel, supra note 5 , at 187-89. 
Second, this rule provides greater assurance that the project will be built. Unless the cost of road construction is greater than the economic rent of the subdivision, it is always profitable for the developer to make some kind of deal. Even if the road construction cost does exceed the economic rent of the project, the community can still reduce the road requirement in exchange for monetary compensation. This result would not occur under a liability rule because the community residents are indifferent between having the road built and getting a limited cash compensation for damages.

\section{VI}

\section{INITIAL ENTITLEMENTS}

If one admits that both the community and the developer have some entitlement to control land use, concern must focus on reasonable division of initial entitlements between them. Examination of the exaction payment itself often obscures the question why the developer should have to pay at all. As a matter of fairness, the community should not be entitled to extract all of the economic rent attendant upon its regulatory decisions. Instead, the community should be entitled to "zero congestion" effects from the development. Requiring zero congestion is consistent with the prevailing economic view that the community has the right to reduce negative externalities, but forcing people to provide positive externalities should be viewed more skeptically. ${ }^{25}$ Such a standard is also consistent with the "harmbenefit" distinction and its variants in the legal literature. ${ }^{26}$ The following example explores this point.

Consider San Francisco's practice of charging commercial developers for permission to develop, with generated revenues earmarked to subsidize lowincome housing. ${ }^{27}$ These schemes have been defended on the dubious ground that commercial development causes a need for low-income housing. But establishing such a linkage is both unnecessary and counterproductive. If new low-income housing is a public good desired by the local electorate, it should be funded by general municipal revenues.

One source of municipal revenues is the sale of permission to develop. The question is what aspects of development the municipality ought to be

25. This point is consistent with the usual policy prescription that positive externalities should receive subsidies by governments, while negative externalities should be the object of taxation. See J. Hirshleifer, Price Theory and Applications 487 (3d ed. 1984); R. Musgrave \& P. Musgrave, supra note 9 , at 78-79.

26. See Ellickson, Suburban Growth Controls: An Economic and Legal Analysis, 86 Yale L. J. 385 (1977); see also E. Freund, The Police Power (1904); Wittman, Liability for Harm or Restitution for Benefit?, $13 \mathrm{~J}$. Legal Stud. 57 (1984).

27. See generally Diamond, The San Francisco Office/Housing Program: Social Policy Linderwritten by Private Enterprise, 7 HaRv. EnVtL. L. Rev. 449 (1983). This exaction program is similar in principle to inclusionary zoning, in which developers of new housing are required, as a price for permission to develop, to subsidize housing for low- and moderate-income families. Clapp, The Impact of Inclusionary Zoning on the Location and Type of Construction Activity, 9 AM. REAL. Est. \& LrB. ECON. J. 436 (1981). It is assumed in the text that such programs could extract pure rents from developers. In practice, they may be administered as taxes on capital, which would discourage construction. 
permitted to regulate and hence grant exceptions to. Once that question is answered, there is no reason to question the uses to which funds raised from granting exceptions should be put. The community, through its political process, can decide to use these revenues for housing, parks, or roads, or simply to reduce local taxes.

What development should the community then be permitted to halt? As suggested above, the harm-benefit test is relevant. ${ }^{28}$ If commercial developments in certain parts of San Francisco impose harm on some neighborhoods, then the community's restrictions are easily rationalized by traditional criteria. The novelty suggested here is that communities should be able to sell exceptions (impose exactions to be used for any municipal purpose) that allow the harm, rather than require developers strictly to avoid the harm. The surplus revenue from such a deal thus becomes part of the city's general revenues, and there is no need to justify any particular use of the funds or earmark them for a special purpose supposedly linked to the development.

If the city is imposing regulations considered unreasonable, for example, because the regulations prevent activities normal for its neighborhoods, then the attack should be on the regulations themselves, not on the purposes for which the exactions are being spent. Thus, developers in San Francisco who must pay exactions for permission to build a hotel in districts in which hotels are normally located are being unreasonably restricted by this standard. ${ }^{29}$ It is the regulation, not the purpose for which the payment is earmarked, that is the source of the burden. Forbidding any payment or earmarking it for something not valued by political authorities will increase the burden on the developer, not decrease it.

That some hotel developers willingly pay these exactions suggests the power of the municipality's position, not the reasonableness of the regulation. Developers may pay exactions for permission to engage in activities they have a right to engage in even when a court is likely to uphold their position. They pay because the project delays caused by challenging the regulation are nonrecoverable expenses under the laws of most states. ${ }^{30}$ Few courts award money damages for unreasonable project delay. ${ }^{31}$

Court-ordered damage payments for excessively burdensome regulations are the mirror image of developer exactions paid to receive exceptions from legal regulations. Both cases involve the sale of regulations in that money is exchanged in order to acquire a new entitlement. It follows that those who

28. See supra note 26 and accompanying text.

29. The case in point was the agreement by Hilton Hotels to pay more than one million dollars into a housing fund for permission to expand its hotel in a commercial area of San Francisco. San Francisco Chronicle, Apr. 2, 1982, at 5, col. 1; see also Share \& Diamond, San Francisco's Office-Housing Production Program, LAND Use L. \& Zoninc Dic., Oct. 1983, at 4.

30. See Kanner, Inverse Condemnation Remedies in an Era of Uncertainty, 1980 INST. ON PLAN. ZoNING \& Eminent Domain 177, 207-09.

31. The argument for damages is presented in Justice Brennan's dissent in San Diego Gas \& Elec. v. City of San Diego, 450 U.S. 621 , 636 (1981) (Brennan, J., dissenting). On the merits of damages as opposed to injunctions generally, see Ellickson, supra note 26, at 490-93. 
approve of land use exactions as a legitimate source of municipal revenue should also approve of payment of money damages for regulatory takings.

\section{VII \\ Who Pays?}

This article has implicitly adopted the view that the developer is the landowner. Thus, when the burden of regulation or taxation is shifted to the developer, it is shifted to the landowner as well. However, when developers can foresee regulations and taxes prior to purchase of the land, the burdens supposedly shifted to the developer are actually shifted to prior landowners. Developers who foresee burdensome regulations will offer less money for the land; this devaluation is thus borne by the earlier landowner. Similarly, regulations anticipated to confer benefits on particular parcels of land will cause developers to bid up their price, so that the original landowner rather than the developer reaps most of the benefit.

In the system of property rule protection against specific spillover effects described above, the developer bears the full burden of the regulation. ${ }^{32} \mathrm{He}$ does so because the efficient outcome is achieved: the houses are built and neighbors are compensated for the congestion effects. The developer may give up some of the economic rent to community residents, but the economic behavior of both parties is not altered. In such a system, the exaction has the same effect as the classical tax on land or the economists' paradigmatic "head tax." "33 Heads, like land, cannot be easily removed from the reach of the tax collector. ${ }^{34}$ Taxes on them therefore cause no change in economic behavior since there is no opportunity to avoid the tax. This unpleasant fact is what makes the tax efficient.

In an efficient system of exactions, the payment is a transfer of land rent to the community. If one thinks that the developer is initially entitled to this rent, the burden of exactions is borne by the developer. Under an inefficient system, the burdens can be shifted to other parties. Because there are so many ways by which land use exactions might be imposed, it is necessary to limit discussion of this problem to the inefficiency caused by the failure of the community and the developer to come to terms because of restraints on alienability. A paradigmatic example of this problem is the developer who was willing to pay up to $\$ 175,000$ to subdivide his four lots into eight lots, but was unable to satisfy the community because the $\$ 175,000$ of earmarked expenditures was insufficient compensation, even though a lesser cash amount would have been sufficient.

The two immediate losers in this case are the community and the developer. A project that generated $\$ 75,000$ in economic rent is unavailable

32. See supra notes $22-31$ and accompanying text.

33. See W. Baumol \& A. Blinder, Economics: Principles and Policy 595 (3d ed. 1985).

34. Land taxes are critically evaluated in E. Mills \& B. Hamilton, Urban Economics 73-78 (1984). 
to them, and each loses in proportion to the expected division of economic rent between them. But there are also other harmed parties. If the developer does not build at all in a particular place, people who would have lived there but now cannot suffer a loss. Of course they can live somewhere else, but to the extent that other locations are not perfect substitutes for the site in question, the unknown housing consumer suffers a loss.

Urban economic analysis suggests that the effect of displacing potential residents is to force development further from urban centers. ${ }^{35}$ The reason is that the major focus of housing development is the suburban edge of metropolitan areas. As these areas are developed, initial residents become concerned with the spillover effects of subsequent development. If there is no mechanism to compensate existing residents who have the power to halt subsequent development, developers will have to go elsewhere. Since suburbs will be likely to imitate one another's controls, the developers' choices for hospitable communities are the central city or rural areas. Construction in the central city often entails costly demolition and working with deteriorated neighborhood conditions. The open spaces of rural areas or small towns avoid both problems. Citizens in such areas are also often eager for development, partly because they own much of the land.

The resulting pattern may aptly be described by the pejorative term "sprawl." Sprawl creates excessive commuting and an excessively decentralized pattern of jobs. The latter result may have the further indirect effect of removing employment opportunities from central cities and thus harming workers who live there.

35. See W. Fischel. supra note 5, at 259-65. 
